\title{
APROPRIAÇÃO DE TERRAS NO BRASIL E O INSTITUTO DAS TERRAS DEVOLUTAS
}

\section{Ionnara Vieira de Araújo ${ }^{1}$}

\section{Maria Cristina Vidotte Blanco Tárrega ${ }^{2}$}

\section{INTRODUÇÃO}

A ocupação do território brasileiro, em função das dificuldades decorrentes das distâncias e do clima, demandou da Coroa Portuguesa a adoção de diversos sistemas como as Capitanias Hereditárias e os Governos Gerais.

Nesta época, as terras estavam fora do comércio. Sua apropriação econômica dependia de favoritismos originados a partir da adoção do regime de sesmarias. Note-se que mesmo nesta época o beneficiário, ou seja, o sesmeiro, tinha por obrigação medir, demarcar e cultivar as terras, sob pena de comisso.

No início do Brasil Império houve a proibição da concessão de sesmarias, sob os argumentos de não estarem produzindo os efeitos de aumentar a povoação do território e de melhorar a produtividade na atividade agrária. Houve, então, a inauguração do assim chamado regime de posses, que vigorou de 1822 até 1850.

Entretanto, mesmo nesta época, o imóvel rural não era instrumento para cumulação de riqueza. A riqueza estava no trabalho escravo, não na propriedade das terras.

Somente em 1850, com a publicação da Lei 601, as terras entraram definitivamente no comércio. A partir daí, a aquisição da propriedade passou a se dar mediante compra e venda.

Modificou-se, enfim, tal como previsto, um regime centenário, o das sesmarias, para um regime de apropriação econômica da terra. A propriedade rural entrou no comércio e

\footnotetext{
${ }^{1}$ Advogada, mestre em Direito Agrário pela UFG, bolsista PIBIC-CNPQ da Universidade Federal de Goiás , Brasil.

${ }^{2}$ Doutora em Direito, é professora titular da Universidade Federal de Goiás e no Programa de Mestrado da Universidade de Ribeirão Preto. Pesquisadora foi bolsista produtividade do CNPq É avaliadora do INEP, supervisora da SESu (ad hoc) e parecerista CNPq (ad hoc). Integra o Conselho Editorial de vários periódicos científicos. É responsável pela Revista da Faculdade de Direito da UFG
} 
tornou-se, mais ainda, instrumento de poder político e econômico. Além disso, deu-se resposta à preocupante questão fundiária brasileira entregue, até então, ao regime de posses com todas as suas mazelas.

Entretanto, a questão fundiária permanece não resolvida. Na verdade, não se sabe, ainda, em sua totalidade, o que é terra devoluta e o que pertence ao patrimônio particular.

Terras devolutas são aquelas que não estando afetadas a algum uso público federal, estadual ou municipal, não caíram regularmente no patrimônio dos particulares. Terras devolutas são espécies de terras públicas.

O Estado Brasileiro é grande possuidor de terras devolutas, mas não sabe exatamente onde estão, nem sua verdadeira extensão. Além disso, sabedor de sua complexa situação fundiária tem clara noção de que não é possível simplesmente arrestar as terras devolutas rumo a seu patrimônio sem trazer severos prejuízos de ordem social.

O referencial teórico utilizado é neo-positivismo que, apesar de não solver todas as dúvidas, abre a perspectiva dos princípios enquanto espécies de normas jurídicas, o que não é pouco em vista da dogmática jurídica anterior. O método é o descritivo já que busca, neste estudo, apresentar os institutos ligados à regularização fundiária e sua relação com as terras devolutas. Isto não significa que não se procederá, nos momentos oportunos, as considerações de ordem crítica que se fizerem necessárias.

\section{1 - APROPRIAÇÃO DE TERRAS NO BRASIL}

\subsection{Brasil Colônia}

A aquisição de terras no Brasil, como meio formal e generalizado, começou na capitania de São Vicente em 1532, e por intermédio de seu donatário Martim Afonso de Souza. Foi a carta de sesmaria o título de concessão dominial, de que lançou mão o colonizador português para a consolidação da conquista do território incorporado ao reino de Portugal, em 1.500, regime que vigorou no Brasil até $1822{ }^{3}$ Havia em Portugal, desde 1.375, na última dinastia Borgonha do rei D. Fernando, o confisco das terras desaproveitadas que

\footnotetext{
${ }^{3}$ JUNQUEIRA, M. O Instituto Brasileiro das Terras Devolutas. São Paulo: Edições LAEL, 1976, p. 11.
} 
deveriam ser entregues a quem as lavrasse, costume este que foi herdado dos belgas e dos galos. (Lei das Sesmarias, publicada em Santarém em 1375). ${ }^{4}$

Juridicamente não houve no Brasil sesmarias e sim datas e concessões da Coroa, que foram largamente utilizadas. Tais concessões possuíam caráter estritamente enfitêutico. No Brasil apenas houve sesmarias regidas pelos forais, debaixo do regime enfitêutico. ${ }^{5}$

Em 1530, D. João II expediu uma carta de poder ou carta de patente a Martim Afonso de Souza, na qual outorgou-lhe poder para, quanto as terras que descobrisse no Brasil, dá-las às pessoas que nelas quisessem viver e povoar . As cartas régias e de foral (1531) e a carta de doação de 1535, também expedidas à Martim Afonso, trataram apenas da capitania de São Vicente. Surge então a concessão enfiteuta, com divisões de poderes e atribuições. Ao donatário, Martim Afonso de Souza, na carta de doação, se atribuiu uma porção da costa brasileira de cem léguas. ${ }^{6}$

Foi a carta de Foral que instituiu no Brasil o sistema de concessões de cartas de sesmarias, debaixo do regime enfitêutico, uma vez que havia uma carta de foral para cada capitania, fazendo corpo com a respectiva carta de doação, outorgada a cada donatário. ${ }^{7}$

Era o Foral uma lei especial, derrogatória do direito comum constante das ordenações do Reino. Foral é a lei dada pelo senhorio direto do respectivo território, diz o Elucidário de Frei Joaquim Rosa de Viterbo, lei, portanto ditada ao titular do domínio útil do imóvel enfitêutico. ${ }^{8}$

A carta de Sesmaria é concessão foreira desde o início, eis que regida pela carta de foral, uma para cada capitania, mas de teor idêntico. Esse foro que no começo era representado pelo dízimo, de caráter modificado, durante a segunda metade do século XVIII, passando a cobrar-se um tanto por légua, segundo a importância das terras. ${ }^{9}$

As sesmarias, (...) antiga tradição jurídica da península Ibérica, nada mais eram do que terras sujeitas a uma obrigação de cultivo, reconhecendo-se agora o direito de propriedade, limitado a essa obrigação (...). O proprietário tinha sobre a terra não um

\footnotetext{
${ }^{4}$ Ibidem, p. 12-13.

${ }^{5}$ COSTA, Helio Roberto Novoa. Discriminação das terras devolutas. São Paulo:Ed. Universitária de Direito, 2000 , p. 32.

${ }^{6}$ JUNQUEIRA, 1976, p. 18-19.

${ }^{7}$ Ibidem, p. 24.

${ }^{8}$ Ibidem, p. 24.

${ }^{9}$ Ibidem, p. 24.
} 
direito real pleno, à semelhança do direito de propriedade de nossos dias, mas limitando-se pela servidão pessoal que lhe era imposta de cultivar a terra. ${ }^{10}$

A divisão do Brasil em capitanias hereditárias foi sugerida a D. João III, pelo diplomata português Diogo de Gouveia, muito entendido de colonização e que tanto gabava o sistema que já havia demonstrado sua eficiência nas Ilhas da Madeira e dos Açoures. A carta régia de 28 de setembro de 1532 dividiu o Brasil em capitanias hereditárias. ${ }^{11}$

Os capitães detinham grande poder político e jurídico, distribuíam as terras da capitania para os sesmeiros que passavam a seus filhos por herança, mas independente de qualquer situação a terra brasileira era parte do patrimônio pessoal do rei. "A propriedade da terra era reservada à coroa. Quem recebia doações não tinha título de proprietário. Podia usufruir apenas da terra."12

A sesmaria, contrato enfitêutico a título perpétuo, era concedida com a obrigação de prestar o dízimo à Ordem de Cristo. Mas o foro na sesmaria brasileira, em vez de ser fixo e anual era retributivo pagos pelos que recebiam terras de sesmarias. A preferência dada ao sistema de ração (pensão ou dízimo) ao foro certo, proveio de ser ele o mais de acordo com as idéias religiosas dos colonos. $^{13}$

O pedido de sesmaria era feito ao capitão mor, capitães generais e governadores da província, identificando o peticionário, o local e área desejada, caracterizada em seus limites e confrontações. Este recebia informações da Fazenda Real do município de situação das terras e do procurador da coroa. Deferido o despacho era lavrado na Secretaria de Estado a carta de sesmaria, título provisório, devendo o interessado requerer ao rei, em três anos, a carta de confirmação, esta a título definitivo. ${ }^{14}$

Ao concessionário corria a obrigação de demarcar as terras, dentro de três anos. $\mathrm{O}$ inadimplemento de qualquer dessas cláusulas acarretaria o comisso da concessão, possibilitando a concessão das terras a outrem. ${ }^{15}$

\footnotetext{
${ }^{10}$ MIRANDA, Custódio da Piedade. Natureza Jurídica das Sesmarias. In: Revista do Direito Agrário. Brasília. 10 (9), p. $9-13,1^{\circ}$ sem. 1983 , p. 10.

${ }^{11}$ JUNQUEIRA, op. cit., p. 21.

${ }^{12}$ VIAL, Sandra Regina. Propriedade da terra: uma análise sociojurídica. Porto Alegre: Livraria do Advogado Editora, 2003, p.164.

${ }^{13}$ JUNQUEIRA, op. cit. , p. 24-25.

${ }^{14}$ Ibidem, p. 29.

${ }^{15}$ Ibidem, p. 29-30.
} 
O certo é que logo de início a sesmaria encontrou na colônia um ótimo campo de aplicação - o latifúndio canavieiro. A colonização rápida do território brasileiro só poderia verificar-se através do latifúndio. ${ }^{16}$

Com a falência da Capitanias Hereditárias, instala-se no Brasil o Governo Geral de 1548, que teve por fim uniformizar a administração do território, submetendo os donatários a uma autoridade superior com sede no Brasil, regime que perdurou até 1808, com a chegada da família real ao Brasil. ${ }^{17}$

Das capitanias hereditárias até a proibição de doações por sesmarias não se viu uma significativa alteração na forma de distribuição de terras baseado em uma política marcada pelos favoritismos. $^{18}$

\section{2- Brasil Império}

José Bonifácio de Andrada e Silva, analisando o quadro territorial do Brasil de então ofereceu instruções no ano de 1.821, aos deputados de São Paulo às Cortes portuguesas, recomendando-lhes:

Que haja uma nova legislação sobre as chamadas sesmarias que, sem aumentar a agricultura, como se pretendia, antes têm dificultado a povoação progressiva e unida porquanto as sesmarias de seis, oito e mais léguas quadradas, possuídas por homens sem cabedais e sem escravos, que não só as não cultivam mas nem sequer as vendem e repartem por quem melhor as saiba aproveitar, originando-se daqui que as povoações do sertão se acham muito espalhadas e isoladas, por causa dos imensos terrenos de permeio, que se não posem repartir e cultivar, por serem sesmarias, seguindo-se também daqui, viver a gente do campo dispersa e como feras no meio das brenhas e matos, com sumo prejuízo da administração d justiça e da civilização conveniente que seguindo-se o espírito da lei do senhor D. Fernando sobre esta matéria, que serviu e fonte ao que está determinado na Ordenação do livro 4, título 43, se legisle, pouco mais ou menos, o seguinte.

4- Que todas as terras que foram dadas por sesmaria e não se acharem cultivadas, entrem outra vez na massa dos bens nacionais, deixando-se somente aos donos das terras, meia légua quadrada, quando muito com a condição de começarem a cultivá-las em tempo determinado, que parece justo.

5- Que os que têm feito suas as terras, só por mera posse e não por título legal, as hajam de perder, exceto o terreno que já tiverem cultivado e mais 400 geiras acadêmicas, para poderem estender a sua cultura, determinando-se-lhes, para isso, tempo prefixo.

\footnotetext{
${ }^{16}$ Ibidem, p.31.

${ }^{17}$ VIAL, 2003, p.166.

${ }^{18}$ VIAL, 2003, p. 175.
} 
6- Que de todas as terras que reverterem por esse modo à nação e de todas as outras que tiverem vagas, não se dêem mais sesmarias gratuitas, senão nos poucos casos abaixo apontados, mas se vendam em porções ou lotes, que nunca possam exceder de meia légua quadrada, avaliando-se, segundo a natureza e bondade das terras, a geira acadêmica de 400 braças quadradas, de sessenta réis para cima e procedendo-se à demarcação legal ${ }^{19}$

José Bonifácio dizia que "as terras que deveriam entrar outra vez na massa dos bens nacionais ou reverter, por esse modo, à nação, seriam exatamente, de 1850 em diante, as terras devolvidas, isto é, as terras devolutas." ${ }^{20}$ Em 17 de julho de 1822 D. Pedro I baixou a resolução do Reino $\mathrm{n}^{\circ} 76$, ratificada pela provisão de 22 de outubro de 1822, suspendendo a concessão de sesmarias, até a ulterior convocação da assembléia geral, Constituinte e Legislativa. $^{21}$

Em 1822, inicia-se no Brasil o Regime da Posse de Terras Devolutas, decorrente da proibição da concessão de sesmarias aliada à falta de uma legislação que regulamentasse o uso e a propriedade da terra, período que se estendeu até 1850 com a promulgação da Lei de Terras. $^{22}$

Ao contrário do regime sesmarial, a posse pressupunha a exploração da terra para depois vir o reconhecimento legal estatal da situação. No início o posseiro ocupava terra de ninguém, nos intervalos das sesmarias. Depois, passa a ocupar as sesmarias abandonadas ou não cultivadas . Chega, por fim, às terras devolutas. Em alguns casos chega ao latifúndio semi explorado. $^{23}$

A Constituição Imperial de 1.824, influenciada pelo pensamento liberalista garantiu o pleno direito de propriedade conforme dispõe no artigo 179:

XXII. E'garantido o Direito de Propriedade em toda a sua plenitude. Se o bem publico legalmente verificado exigir o uso, e emprego da Propriedade do Cidadão, será elle préviamente indemnisado do valor della. A Lei marcará os casos, em que terá logar esta unica excepção, e dará as regras para se determinar a indenização. ${ }^{24}$

\footnotetext{
${ }^{19}$ JUNQUEIRA, 1976, p. 36-38.

${ }^{20}$ Ibidem, p. 36-38.

${ }^{21}$ COSTA, 2000, p.44.

${ }^{22}$ VIAL, 2003, p.178.

${ }^{23}$ SANTOS, Fábio Alves. Direito Agrário: Política Fundiária no Brasil. Belo Horizonte: Del. Rey, 1995 , p. 63.

${ }^{24}$ BRASIL. Constituição Política Do Império Do Brazil (de 25 de março de 1824). <http://www.planalto.gov.br/ccivil_03/Constituicao/Constitui\%C3\%A7ao24.htm >.Acesso 01 abr. 2009, $15: 23: 14$.
} 
Neste período a situação fundiária do país era composta por: Sesmarias concedidas e integralmente confirmadas, o proprietário tinha sobre elas o domínio legal; Sesmarias concedidas mas não confirmadas, tinham a posse mas não o domínio; Glebas ocupadas por posses, sem qualquer título, configurando-se a situação de fato por ocupação com ou sem exploração efetiva e; terras sem ocupação não concedidas ou já revertidas ao Poder Público, ou seja terras devolutas. ${ }^{25}$

Até a segunda metade do século XIX a propriedade da terra era estatal ou semi-estatal, não podia ser comprada nem vendida. Somente a partir de 1850 se pode falar em propriedade privada da terra. ${ }^{26}$

Com a suspensão da concessão de sesmarias em 1822, ocorreu um período de lacuna legal, onde a única forma de aquisição de propriedade era por meio da ocupação, verificandose a ausência do Estado em relação à aquisição da terra. ${ }^{27} \mathrm{Na}$ verdade, o território brasileiro esteve de julho de 1822, até a vigência da Lei 601, de 18 de setembro de 1850, com tolerância do governo imperial, à mercê de quem quisesse pura e simplesmente ocupá-lo. ${ }^{28}$

Nesta fase extralegal as terras brasileiras encontravam-se: Integrando o patrimônio de particulares originários de sesmarias, que cumpriram os requisitos legais; na posse de particulares também originários de sesmarias, mas que não cumpriram os requisitos legais e por isso não obtiveram a confirmação da doação; na posse de particulares sem nenhum título hábil; integrando o patrimônio público desde a colonização, sem terem sido dadas em sesmarias ou ocupadas; e, devolutas propriamente ditas, que são as terras que caíram em comisso, devolvidas ao patrimônio imperial. ${ }^{29}$

$\mathrm{Na}$ ordem de 18 de abril de 1.842, "declarou-se que, para um terreno aforado ficar legalmente devoluto, é preciso que o foreiro seja convencido e julgado em comisso pelos meios judiciais." 30

A Lei de Terras, como ficou conhecida a Lei n. 601 de 1850, é um documento fundamental para compreender a organização agrária do Brasil. Ela atendia à evidente necessidade de organizar a situação dos registros das terras concedidas desde o período

\footnotetext{
${ }^{25}$ SANTOS, F., 1995, p. 65.

${ }^{26}$ Ibidem p. 66.

${ }^{27}$ Ibidem, p. 61.

${ }^{28}$ JUNQUEIRA, 1976, p. 38.

${ }^{29}$ SOUSA, João Bosco. Direito Agrário: Lições Básicas. 3.ed. São Paulo, Saraiva, 1994, p. 20.

${ }^{30}$ JUNQUEIRA, 1976, p. 74.
} 
colonial e legalizar as terras ocupadas sem autorização, para depois reconhecer as chamadas terras devolutas, pertencentes ao Estado. Logo, também deu suporte para que se processassem as transformações capitalistas no Brasil. ${ }^{31}$

Esta lei objetivou, impedir que os escravos livres pudessem se apossar de terras, vez que em 1830 já havia cessado o tráfico de escravos, em razão do artigo $1^{\circ}$. da lei de 7 de outubro de 1831 - "Todos os escravos que entrarem no território e portos do Brasil, vindos de fora ficam livres." 32

O registro paroquial, previsto na Lei de Terras, não era considerado título de domínio, tratava-se de mero recenseamento de possuidores de terras, já que não conferia direito aos registrantes (art. 94 do decreto 1318 de 1854). Segundo Messias Junqueira "se não fosse a cobrança por letras o registro paroquial seria um ótimo cadastro de terras possuídas àquele tempo, mas hoje dificilmente identificáveis, em razão da concisão dos registrantes a fim de pagarem menos." 33

\begin{abstract}
Os sagrados direitos de propriedade, o dogma da liberdade do domínio sempre foram argumentos que se levantam, com maior ou menor desenvoltura, quando se deseja contrapor às decorrências da titulação a realidade de uma produção, de um trabalho enfim, que se realiza à margem da formalidade- seja perante os pretores (em Roma), os donatários (no Brasil das capitanias hereditárias), a Coroa (no Império), ou agora perante a União, Estados e Municípios (no caso das Terras Devolutas) e os titulares de domínio, confiados apenas na exatidão do brocardo 'só é dono quem registra'. ${ }^{34}$
\end{abstract}

Rompendo a estrutura latifundiária, a Lei 601 de 1.850, possibilitou no Brasil a formação da pequena propriedade. Já que a propriedade da terra de privilégio passou a ser mercadoria. Democratizou a estrutura social com a nobilitação do posseiro, dando-lhe status. O destino dessa lei, cujas raízes mergulham nas aspirações de nossa independência política, era romper o etos cultural contemporâneo da conquista, fazendo-se presente no primeiro golpe vibrados contra as instituições liberticidas, para ajudar depois na grande obra de composição pacífica e definitiva do território. ${ }^{35}$

\footnotetext{
${ }^{31}$ MARQUES, Daiane da Cunha. Uma Análise Sócio- Jurídica da Parceria Rural em Ervália - MG. 2007. 138f. Dissertação (Pós-Graduação em Extensão Rural)- Universidade Federal de Viçosa, Viçosa, Minas Gerais ,2007, p. 31.

32 JUNQUEIRA, 1976, p. 78.

${ }^{33}$ Ibidem, p. 78.

${ }^{34}$ ALVARENGA, Octávio Mello. Contratos agrários. Brasília: Fundação Petrônio Portella, 1982. (Curso de Direito Agrário, 8), p. 17.

${ }^{35}$ JUNQUEIRA. op. cit., p. 91.
} 
A Lei 601 de 1850, dispõe sobre as terras devolutas no Império, e acerca das que são possuídas por titulo de sesmaria sem preenchimento das condições legais, bem como por simples titulo de posse mansa e pacifica. Além disso, esta Lei determina que, medidas e demarcadas as terras devolutas, sejam elas cedidas a titulo oneroso. Prevê que "Art. $1^{\circ}$ Ficam prohibidas as acquisições de terras devolutas por outro titulo que não seja o de compra." E que: "Exceptuam-se as terras situadas nos limites do Imperio com paizes estrangeiros em uma zona de 10 leguas, as quaes poderão ser concedidas gratuitamente. „36

Embora não se pudesse conceder novas sesmarias a lei de terras permitiu a revalidação das sesmarias, ou outras concessões do Governo Geral ou Provincial, que se acharem cultivadas, ou com princípios de cultura, e morada habitual do respectivo sesmeiro ou concessionário, ou do quem os represente, embora não tenha sido cumprida qualquer das outras condições, com que foram concedidas. ${ }^{37}$

Esta lei também legitimou as posses mansas e pacificas, adquiridas por ocupação primária, ou havidas do primeiro ocupante, que se acharem cultivadas, ou com principio de cultura, e morada, habitual do respectivo posseiro, ou de quem o represente. ${ }^{38}$ Quanto a demarcação da posse a lei de terras diz:

\begin{abstract}
Art. $7^{\circ} \mathrm{O}$ Governo marcará os prazos dentro dos quais deverão ser medidas as terras adquiridas por posses ou por sesmarias, ou outras concessões, que estejam por medir, assim como designará e instruirá as pessoas que devam fazer a medição, attendendo ás circumstancias de cada Provincia, comarca e municipio, o podendo prorogar os prazos marcados, quando o julgar conveniente, por medida geral que comprehenda todos os possuidores da mesma Provincia, comarca e municipio, onde a prorogação convier.

Art. $8^{\circ}$ Os possuidores que deixarem de proceder á medição nos prazos marcados pelo Governo serão reputados cahidos em commisso, e perderão por isso o direito que tenham a serem preenchidos das terras concedidas por seus titulos, ou por favor da presente Lei, conservando-o sómente para serem mantidos na posse do terreno que occuparem com effectiva cultura, havendo-se por devoluto o que se achar inculto. ${ }^{39}$
\end{abstract}

Portanto, numa linguagem mais aproximada do atual contexto histórico, o fim do regime de sesmarias (lei de 17 de julho de 1822), e a edição da lei de terras (1850),

\footnotetext{
${ }^{36}$ BRASIL. Lei ${ }^{\circ}$ 601, de 18 de setembro de 1850.Disponível em:

. htttp://www.planalto.gov.br/ccivil_03/Leis/LIM/LIM601.htm>. Acesso em 01 abr. 2009. 17:12:54.

${ }^{37}$ Ibidem.

${ }^{38}$ Ibidem.

${ }^{39}$ Ibidem. .
} 
democratizaram o acesso à terra, pois extinguiram o sistema de concessões que permitia o acesso somente dos bem relacionados com a Corôa.

\subsection{Brasil República}

Na primeira Constituição Republicana, de 1.891, houve a transferência das terras de uso público da União para os Estados. Tal fato produziu desarmonia federativa, pois, cada Estado deu solução diversa para a questão fundiária, não havendo controle da União. ${ }^{40}$

Segundo o artigo 67 da Constituição de 1891: "Pertencem aos Estados as minas e terras devolutas situadas nos seus respectivos territórios, cabendo à União somente a porção do território que for indispensável para a defesa das fronteiras, fortificações, construções militares e estradas de ferro federais. ${ }^{41}$

O Código Civil de 1916 estabeleceu a via judicial para a discriminação das terras devolutas pertencentes aos Estados. Neste período não se aceitava mais a revalidação das sesmarias, e nem era possível a legitimação da posse, mas era possível a aquisição por usucapião. $^{42}$

A Constituição dos Estados Unidos do Brasil, de 10 de novembro de 1937, de cunho eminentemente autoritário, foi um retrocesso na evolução do direito de propriedade no Brasil, já que não trouxe em seu texto o sentido social do direito de propriedade dado pela Constituição de 1934.

A Constituição de 1.946 assim dispôs sobre o direito de propriedade:

Art. 141. A Constituição assegura aos brasileiros e estrangeiros residentes no país a inviolabilidade dos direitos concernentes à vida, à liberdade, à segurança individual e à propriedade, nos termos seguintes:

$\S 16$ - É garantido o direito de propriedade, salvo o caso de desapropriação por necessidade ou utilidade pública, ou por interesse social, mediante prévia e justa indenização em dinheiro.

\footnotetext{
${ }^{40}$ VIAL, 2003, p. 185.

${ }^{41}$ BRASIL. Constituição Da República Dos Estados Unidos Do Brasil ( De 24 De Fevereiro De 1891) . Disponível em: .<http://www.planalto.gov.br/ccivil_03/Constituicao/Constitui\%C3\%A7ao91.htm>. Acesso 01 abr. 2009, 15:23:14.

${ }^{42}$ VIAL. op. cit. p. 185 .
} 
Art. 147 - O uso da propriedade será condicionado ao bem-estar social. A lei poderá, com observância do disposto no art. 141, § 16, promover a justa distribuição da propriedade, com igual oportunidade para todos. 43

Esta Constituição além de ter condicionado o uso da propriedade ao bem-estar social ainda estabeleceu a desapropriação por interesse social. Nela os brasileiros são incluídos no acesso à terra. Mas embora previsse a justa distribuição de terras, ainda se desconhece a sua efetividade.

Art 34 - incluem-se entre os bens da União:

II - a porção de terras devolutas indispensável à defesa das fronteiras, às fortificações, construções militares e estradas de ferro. ${ }^{44}$

A Constituição de 1.967, trouxe quanto o regime das terras devolutas: "Art. $5^{\circ}$ Incluem-se entre os bens dos Estados os lagos e rios em terrenos de seu domínio e os que têm nascente e foz no território estadual, as ilhas fluviais e lacustres e as terras devolutas não compreendidas no artigo anterior". 45

Finalmente, a Constituição Federal de 1988 traz como bens da União somente as terras devolutas indispensáveis à defesa das fronteiras, das fortificações e construções militares, das vias federais de comunicação e à preservação ambiental, definidas em lei, incluindo entre os bens dos Estados as terras devolutas não compreendidas entre as da União. Previu também que a destinação de terras públicas e devolutas será compatibilizada com a política agrícola e com o plano nacional de reforma agrária. ${ }^{46}$

Embora o art. $5^{\circ}$ da Constituição de 1988 garanta aos brasileiros e aos estrangeiros residentes no País a inviolabilidade do direito à propriedade, ao estrangeiro é limitada a aquisição da propriedade rural: conforme se enuncia: “Art. 190. A lei regulará e limitará a aquisição ou o arrendamento de propriedade rural por pessoa física ou jurídica estrangeira e

\footnotetext{
${ }^{43}$ BRASIL. Constituição dos Estados Unidos do Brasil (De 18 de Setembro de 1946). Disponível em: .< http://www.planalto.gov.br/ccivil_03/Constituicao/Constitui\%C3\%A7ao46.htm>. Acesso 01 abr. 2009, 16:23:12.

${ }^{44}$ Ibidem.

${ }^{45}$ BRASIL. Constituição da República Federativa do Brasil de 1.967. Disponível em: .<http://www.planalto.gov.br/ccivil_03/Constituicao/Constitui\%C3\%A7ao67.htm>. Acesso: 02 abril 2009, 12:36:11.

${ }^{46}$ BRASIL. Constituição da República Federativa do Brasil de 1.988. Disponível em: .< http://www.planalto.gov.br/ccivil_03/Constituicao/Constitui\%C3\%A7ao.htm>. Acesso: 13 abr. 2009, 18:36:08.
} 
estabelecerá os casos que dependerão de autorização do Congresso Nacional." 47 Quanto as terás públicas também foi previsto pela Constituição de 1988 que:

\begin{abstract}
ADCT- Art. 51. Serão revistos pelo Congresso Nacional, através de Comissão mista, nos três anos a contar da data da promulgação da Constituição, todas as doações, vendas e concessões de terras públicas com área superior a três mil hectares, realizadas no período de $1^{\circ}$ de janeiro de 1962 a 31 de dezembro de 1987.

$\S 1^{\circ}$ - No tocante às vendas, a revisão será feita com base exclusivamente no critério de legalidade da operação.

$\S 2^{\circ}$ - No caso de concessões e doações, a revisão obedecerá aos critérios de legalidade e de conveniência do interesse público.

$\S 3^{\circ}$ - Nas hipóteses previstas nos parágrafos anteriores, comprovada a ilegalidade, ou havendo interesse público, as terras reverterão ao patrimônio da União, dos Estados, do Distrito Federal ou dos Municípios. ${ }^{48}$
\end{abstract}

Assim, a evolução constitucional e legislativa, do direito à terra, no direito brasileiro, é claramente no sentido de expandir tal garantia a todos, na forma da lei, desde que vinculada aos interesses sociais o que significa, desde que haja o efetivo cumprimento de sua função social.

\title{
2- TERRAS DEVOLUTAS
}

\section{1- Definição Legal e Doutrinária}

A Concepção de terras devolutas no Império era a de terras desocupadas ou devolvidas à Coroa Portuguesa (por incorrerem os beneficiários das sesmarias em comisso). Já na República, terras ocupadas podiam ser consideradas devolutas, desde que não pertencessem ao particular. Segundo a Lei de Terras ( art. $3^{\circ}$ ) são terras devolutas:

$\S 1^{\circ}$ - As que não se acharem aplicadas a algum uso público, nacional, provincial ou municipal.

$\S 2^{\circ}$ - As que não se acharem em domínio particular por qualquer título legítimo, nem forem havidas por sesmarias e outras concessões do Governo Geral ou Provincial, não incursas em comisso por falta do cumprimento das condições de medição, confirmação e cultura.

$\S$ As que não se acharem dadas por sesmarias, ou outras concessões do Governo, que, apesar de incursas em comisso, forem revalidadas por esta Lei.

$\S$ As que não se acharem ocupadas por posses, que, apesar de não se fundarem em título legal, forem legitimadas por esta Lei.

\footnotetext{
${ }^{47}$ BRASIL. Constituição da República Federativa do Brasil de 1.988.

${ }^{48}$ Ibidem.
} 
O mais importante objetivo da Lei de Terras foi conferir titulação a todos aqueles que não a tinham, embora ocupassem terras consideradas devolutas, evitando perpetuar o regime de posses instaurado com a suspensão das sesmarias. Em 1946, o Decreto-lei n ${ }^{\circ}$ 9.760, tratando do patrimônio imobiliário da União, veio a definir terras devolutas como:

Art. $5^{\circ}$ São devolutas, na faixa da fronteira, nos Territórios Federais e no Distrito Federal, as terras que, não sendo próprios nem aplicadas a algum uso público federal, estadual territorial ou municipal, não se incorporaram ao domínio privado:

a) por força da Lei $\mathrm{n}^{\circ} 601$, de 18 de setembro de 1850, Decreto $\mathrm{n}^{\circ} 1.318$, de 30 de janeiro de 1854 , e outras leis e decretos gerais, federais e estaduais;

b) em virtude de alienação, concessão ou reconhecimento por parte da União ou dos Estados;

c) em virtude de lei ou concessão emanada de governo estrangeiro e ratificada ou reconhecida, expressa ou implicitamente, pelo Brasil, em tratado ou convenção de limites;

d) em virtude de sentença judicial com força de coisa julgada;

e) por se acharem em posse contínua e incontestada com justo título e boa fé, por termo superior a 20 (vinte) anos;

f) por se acharem em posse pacífica e ininterrupta, por 30 (trinta) anos, independentemente de justo título e boa fé;

g) por força de sentença declaratória proferida nos termos do art. 148 da Constituição Federal, de 10 de Novembro de 1937.

Segundo José Cretella Júnior, o termo terras devolutas designa não só as terras que foram devolvidas ao patrimônio público como as que nunca tiveram proprietário e são do Estado. ${ }^{49}$ Outros autores como Altir de Souza Maia conceituam terras devolutas, espécie do gênero de terras públicas, como

[...] aquelas terras que, tendo sido dadas em sesmarias, foram, posteriormente, em virtude de haverem caído em comisso, devolvidas à Coroa. Pelo menos, foi esse, originariamente, o conceito que as nominava, evoluindo, ao depois, para a definição contemplada no Decreto- lei $\mathrm{n}^{\circ} 9.760 / 46$, art. $5^{\circ}$, i. e., são devolutas as terras que não se acharem aplicadas a algum uso público federal, estadual ou municipal, ou que não hajam, legitimamente, sido incorporadas ao domínio privado. ${ }^{50}$

Por fim terras devolutas são terras não incorporadas ao patrimônio particular e que não se encontram destinadas a um uso específico pelo poder público.

O Juiz Federal Dirley da Cunha Júnior estabelece uma distinção entre terras públicas (lato sensu e stricto sensu) e terras devolutas. Segundo ele:

\footnotetext{
${ }^{49}$ CRETELA JUNIOR, 1984, p. 348.

${ }^{50}$ Apud ALMEIDA, 2003, p. 313.
} 
são terras públicas todas aquelas pertencentes ao poder público, ou seja, são bens públicos determinados ou determináveis que integram o patrimônio público, incluindo-se, aí, as terras devolutas. Assim, as terras devolutas são espécie de terras públicas lato sensu. A outra espécie são as terras públicas stricto sensu. Temos, pois, duas espécies de terras públicas lato sensu (gênero): as terras devolutas e as terras públicas stricto sensu. ${ }^{51}$

A simples posse, sem titulação, não legitimada, não retira de uma terra, ainda que efetivamente ocupada e com morada habitual de seu possuidor, o caráter de terra devoluta. Por isso, melhor parece ser o conceito de Luís de Lima Stefanini, quando manifesta seu entendimento sobre terras devolutas "como sendo aquelas espécies de terras públicas (sentido lato) não integradas ao patrimônio particular, nem formalmente arrecadas ao patrimônio público, que se acham indiscriminadas no rol dos bens públicos por devir históricopolítico". 52

\subsection{Titularidade e Destinação}

As terras devolutas podem ter natureza de bens públicos dominicais quando são terras públicas do domínio privado do Estado, portanto, disponíveis, nos termos do artigo 101 do Código Civil. E de outra natureza quando se trata de bens públicos de uso especial, como, e.g., as terras devolutas ou arrecadadas pelos Estados, por ações discriminatórias, necessárias à proteção dos ecossistemas naturais, conforme o artigo 225, § 5º da Constituição de 1988.

A propriedade dos bens públicos está traçada, na Constituição, art. 20, II: “São bens da União: as terras devolutas indispensáveis à defesa das fronteiras, das fortificações e construções militares, das vias federais de comunicação e à preservação ambiental, definidas em lei". E também art. 26, IV que trata dos bens dos Estados neles incluídos: "as terras devolutas não compreendidas entre as da União". A jurisprudência sobre o assunto:

AÇÃO CIVIL PÚBLICA. VENDA A NON DOMINO. TERRAS DEVOLUTAS SITUADAS NA FAIXA DE FRONTEIRA. ENTENDIMENTO PACIFICADO PELO SUPREMO TRIBUNAL FEDERAL. CONSTITUIÇÃO DE 1946. 1. O Supremo Tribunal Federal, no julgamento do Recurso Extraordinário n. 52.331, definiu que as terras devolutas situadas na faixa de fronteira, tidas como zona

\footnotetext{
${ }^{51}$ CUNHA JÚNIOR, Dirley da, Terras devolutas nas constituições republicanas Disponível em:. <http://www.jfse.jus.br//obras\%20mag/artigoterrasdevdirley.html>. Acesso em: 25 maio 2008.

52 Apud LEITE, 2004., p. 9.
} 
indispensável à defesa do País até o limite de 150 Km, são de domínio da União. [...] 3. As terras devolutas tidas por indispensáveis à defesa nacional, assim consideradas as situadas na faixa de fronteira, não podem ser transferidas pelos Estados-Membros a particulares sob pena de caracterizar venda a non domino, uma vez que se trata de terras dominicais da União, conforme entendimento manifestado pelo STF [...]( REsp 680860 / PR RECURSO ESPECIAL 2004/0112244-0, DJ 12.02.2008, p. 1)

Analisando os dispositivos acima conclui-se que todas as terras devolutas brasileiras pertencem ou à União ou aos Estados. Em síntese, não há terras devolutas municipais. São de propriedade da União apenas aquelas indispensáveis à defesa das fronteiras brasileiras, das fortificações e construções militares, das vias federais de comunicação e à preservação ambiental, nos termos definidos em lei. Todas as demais pertencem aos estados-membros, de acordo com a sua localização. Nestes termos é a Súmula n. 477 do STF: “As concessões de terras devolutas situadas na faixa de fronteira, feitas pelos estados, autorizam, apenas, o uso, permanecendo o domínio com a união, ainda que se mantenha inerte ou tolerante, em relação aos possuidores."

O poder público, em regra, deve destinar as terras devolutas existentes para fins de colonização e Reforma Agrária sobre isso a Constituição leciona: “Art. 188. A destinação de terras públicas e devolutas será compatibilizada com a política agrícola e com o plano nacional de reforma agrária."

Exceto para fins de reforma agrária, todas as alienações ou concessões de terras públicas, a qualquer título, com área superior a dois mil e quinhentos hectares a pessoa física ou jurídica, ainda que por interposta pessoa, dependerá de prévia aprovação do Congresso Nacional. ( $\$ 1^{\circ}$ e $2^{\circ}$, art. $\left.188, C F\right)$

Não se admite usucapião de terras devolutas por estas serem consideradas bens públicos em sentido estrito. O Supremo Tribunal Federal, pacificou o entendimento jurisprudencial, com a Súmula $n^{0}$ 340: "Desde a vigência do Código Civil, os bens dominicais, como os demais bens públicos, não podem ser adquiridos por usucapião".

Por fim diante do histórico dentro do qual formou-se o patrimônio imobiliário privado no Brasil (do qual exigiu-se, primeiramente - ainda que sem validade formal - a inscrição nos Livros Paroquiais; e, depois - então com validade formal - no Registro de Imóveis), é possível extrair a conclusão de que podem ser identificadas, com relativa precisão, as terras pertencentes a particulares. Daí o sentido da ação discriminatória - aquela que visa a separar 
as terras do domínio público das do domínio particular - que se funda na verdade da assertiva: "no Brasil, todas as terras são públicas, exceto as que são particulares" 53 .

\section{DISCRIMINAÇÃO DAS TERRAS DEVOLUTAS}

Discriminação de terras devolutas é a operação do Estado cujo objetivo é estabelecer a natureza jurídica da terra, decifrando se a gleba é de domínio público ou privado. ${ }^{54}$

O artigo 11 do Estatuto da Terra (Lei 4.504/64) previu que o Instituto Brasileiro de Reforma Agrária, atual Instituto Nacional de Colonização e Reforma Agrária, está investido de poderes de representação da União, para promover a discriminação das terras devolutas federais e com autoridade para reconhecer as posses legítimas manifestadas através de cultura efetiva e morada habitual, bem como para incorporar ao patrimônio público as terras devolutas federais ilegalmente ocupadas e as que se encontrarem desocupadas.

Na realidade a ação do INCRA não é a de representante da União e sim de substituto processual, pois ele age em nome próprio na defesa de direito da União Federal. ${ }^{55}$

A lei $\mathrm{n}^{\circ}$ 6.383, de 7 de dezembro de 1976, dispõe sobre o processo discriminatório de terras devolutas da União. Visa-se com a ação discriminatória separar as terras devolutas das particulares, verificando-se quem tem posse legítima.

O tribunal pleno do STF julgando a ação cível originária, proposta pelo Instituto Nacional de Colonização e Reforma Agrária - INCRA conta o estado do Tocantins e outros o seguinte:

EMENTA: Ação Cível Originária. - São da União as glebas que, anteriormente à edição do Decreto-Lei n ${ }^{\circ} 2375 / 87$, tinham sido incorporadas ao patrimônio dela pelo Decreto-Lei $\mathrm{n}^{\circ} 1164 / 71$ (cuja constitucionalidade se reconhece), e que foram excepcionadas por ele de seu âmbito de aplicação por estarem registradas, na forma da lei, em nome de pessoa jurídica pública e por configurarem objeto de situação jurídica, já constituída ou em processo de formação, a favor de alguém. Ação julgada procedente, sendo a reconvenção julgada improcedente. ${ }^{56}$

\footnotetext{
${ }^{53}$ LEITE, 2004, p. 20

${ }^{54}$ CRETELLA JUNIOR, 1984, p. 348.

${ }^{55}$ BORGES, Marcos Afonso. Processo Judicial da Ação Discriminatória. Goiânia:AB, 1998, p.42.

${ }^{56}$ ACO 477 / TO - TOCANTINS Relator(a): Min. MOREIRA ALVES Julgamento: 27/06/2002 Publicação DJ 01-08-2003 PP-00099, Disponível em: . <http://www.stf.jus.br/portal/jurisprudencia/listarJurisprudencia.asp?s1=(ACO\$.SCLA.\%20E\%20477.NUME.) \%20OU\%20(ACO.ACMS.\%20ADJ2\%20477.ACMS.)\&base=baseAcordaos>. Acesso em 15 abr. 2009.
} 


\begin{abstract}
Ilhas marítimas (ilhas costeiras ou continentais e ilhas oceânicas ou pelágicas). Santa Catarina. Ilha costeira. Usucapião de áreas de terceiros nela existentes. Domínio insular da união federal (cf, art. 20, iv). Possibilidade jurídico-constitucional de existirem, nas ilhas marítimas, áreas sujeitas à titularidade dominial de terceiros (cf, art. 26, ii, in fine). A questão das terras devolutas. Inexistência de presunção juris tantum do caráter devoluto dos imóveis pelo só fato de não se acharem inscritos no registro imobiliário. Insuficiência da mera alegação estatal de tratar-se de imóvel pertencente ao domínio público. Afirmação que não obsta a posse "ad usucapionem". Necessidade de efetiva comprovação, pelo poder público, de seu domínio. Doutrina. Jurisprudência. Domínio da união federal não comprovado, no caso. Possibilidade de usucapião. Matéria de prova. Pronunciamento soberano do tribunal recorrido. Súmula 279/stf. Recurso extraordinário não conhecido. (RE $\mathrm{n}^{\mathrm{o}}$ 285.615, Rel. Min. CELSO DE MELLO, DJ de 23.02.2005. E ainda: RE $\mathrm{n}^{\mathbf{o}}$ 372.166, Rel. Min. CARLOS VELLOSO, DJ de 04.02.05; RE n⿳0 446.953, DJ de 03.06.2005, e $\mathrm{AI} \mathrm{n}^{\circ}$ 421.887, DJ de 01.12.2004, Relator Ministro CEZAR PELUSO).
\end{abstract}

O caráter devoluto da gleba de terra durante a discriminação precisa ser declarado anteriormente pela autoridade competente. A ação discriminatória somente se aplica a Terras Devolutas, para a apuração dos demais bens públicos se aplica a ação de demarcação de terras. $^{57}$

\title{
3.1. Procedimento Administrativo
}

O processo discriminatório será administrativo ou judicial. O processo discriminatório administrativo será instaurado por Comissões Especiais constituídas de três membros, a saber: um bacharel em direito do Serviço Jurídico do Instituto Nacional de Colonização e Reforma Agrária - INCRA, que a presidirá; um engenheiro agrônomo e um outro funcionário que exercerá as funções de secretário.

A Comissão Especial instruirá inicialmente o processo com memorial descritivo da área, no qual constará: o perímetro com suas características e confinância, certa ou aproximada, aproveitando, em princípio, os acidentes naturais; a indicação de registro da transcrição das propriedades; o rol das ocupações conhecidas; o esboço circunstanciado da gleba a ser discriminada ou seu levantamento aerofotogramétrico; e, outras informações de interesse. ( Art. 3º lei no 6.383/ 76).

O edital de convocação conterá a delimitação perimétrica da área a ser discriminada com suas características e será dirigido, nominalmente, a todos os interessados, proprietários, ocupantes, confinantes certos e respectivos cônjuges, bem como aos demais interessados

\footnotetext{
${ }^{57}$ Helio Roberto Novoa COSTA. Discriminação das terras devolutas. 2000, p.116-117.
} 
incertos ou desconhecidos. O edital deve ser afixado em lugar público na sede dos municípios e distritos, onde se situar a área nele indicada; com publicação simultânea, por duas vezes, no Diário Oficial da União, nos órgãos oficiais do Estado ou Território Federal e na imprensa local, onde houver, com intervalo mínimo de 8 (oito) e máximo de 15 (quinze) dias entre a primeira e a segunda.

Reconhecida a existência de dúvida sobre a legitimidade do título, o presidente da Comissão Especial reduzirá a termo as irregularidades encontradas, encaminhando-o à Procuradoria do Instituto Nacional de Colonização e Reforma Agrária - INCRA, para propositura da ação competente. (art. $8^{\circ}$ )

Concluídos os trabalhos demarcatórios, o presidente da Comissão Especial mandará lavrar o termo de encerramento da discriminação administrativa, do qual constarão, obrigatoriamente: I - o mapa detalhado da área discriminada; II - o rol de terras devolutas apuradas, com suas respectivas confrontações; III - a descrição dos acordos realizados; IV - a relação das áreas com titulação transcrita no Registro de Imóveis, cujos presumidos proprietários ou ocupantes não atenderam ao edital de convocação ou à notificação (artigos $4^{\circ}$ e 10 desta Lei); V - o rol das ocupações legitimáveis; VI - o rol das propriedades reconhecidas; e VII - a relação dos imóveis cujos títulos suscitaram dúvidas. (Art. 12 )

Encerrado o processo discriminatório, o Instituto Nacional de Colonização e Reforma Agrária - INCRA providenciará o registro, em nome da União, das terras devolutas discriminadas, definidas em lei, como bens da União.

\subsection{Procedimento Judicial}

$\mathrm{Na}$ discriminação judicial das terras devolutas da União o Instituto Nacional de Colonização e Reforma Agrária - INCRA fica investido de poderes de representação da União. O processo discriminatório judicial será promovido: quando o processo discriminatório administrativo for dispensado ou interrompido por presumida ineficácia; contra aqueles que não atenderem ao edital de convocação ou à notificação da discriminação administrativa; e quando configurada alteração de quaisquer divisas na área discriminada, a derrubada da cobertura vegetal, a construção de cercas e transferências de benfeitorias a qualquer título, sem assentimento do representante da União. 
Pontes de Miranda, juntamente com a maioria da doutrina entendem ter a ação discriminatória natureza jurídica de ação declaratória, entendendo que a sentença não atribui domínio ao autor, pois este preexiste à propositura da ação, tendo pois a sentença efeito meramente declaratório do domínio estatal. Diferentemente, Marcos Afonso Borges entende ser constitutiva-condenatória a natureza da ação discriminatória.

A Justiça Federal é competente para processar e julgar o processo discriminatório judicial. No processo discriminatório judicial será observado o procedimento sumário de que trata o Código de Processo Civil. A petição inicial será instruída com o memorial descritivo da área. A citação será feita por edital, e da sentença proferida caberá apelação somente no efeito devolutivo, facultada a execução provisória.

A demarcação da área será procedida, ainda que em execução provisória da sentença, valendo esta, para efeitos de registro, como título de propriedade. O processo discriminatório judicial tem caráter preferencial e prejudicial em relação às ações em andamento, referentes a domínio ou posse de imóveis situados, no todo ou em parte, na área discriminada, determinando o imediato deslocamento da competência para a Justiça Federal.

Sempre que se apurar, através de pesquisa nos registros públicos, a existência de domínio particular em áreas rurais declaradas indispensáveis à segurança e ao desenvolvimento nacionais, a União, desde logo, as arrecadará mediante ato do presidente do Instituto Nacional de Colonização e Reforma Agrária - INCRA, do qual constará: a circunscrição judiciária ou administrativa em que está situado o imóvel, conforme o critério adotado pela legislação local; e, a eventual denominação, as características e confrontações do imóvel.

O procedimento acima descrito aplica-se no que couber terras devolutas estaduais, em conformidade do que dispuser a Lei de Organização Judiciária local. ${ }^{58}$

\section{CONSIDERAÇÕES FNAIS}

\footnotetext{
${ }^{58}$ Ação discriminatória de terras devolutas de estado-membro.competência. e estadual a competência para processar e julgar a ação, a míngua de interesse da união. a hipótese não se enquadra no art. 109-i da constituição. Conflito conhecido e declarada competente a justiça estadual. (CC 14729 / SC Conflito de Competência 1995/0039635-, DJ 18.12.1995 p. 44457)
} 
No período colonial esta ocupação foi marcada pelos favoritismos do regime de sesmarias. Durante o Império com a proibição da concessão de sesmarias, inauguro-se um período de lacuna legal denominado o regime de posses, que vigorou de 1822 até 1850, não havendo neste período regras para a ocupação territorial, já que, neste período, a riqueza estava no trabalho escravo e não na propriedade das terras.

Com a Lei de Terras, regularizou-se os registros das terras concedidas desde o período colonial e legalizou as terras ocupadas sem autorização, além de reconhecer as terras devolutas. Esta lei, mais do que regularizar a situação fundiária do país, objetivou impedir que os escravos livres pudessem se apossar de terras, vez que em 1830 já havia cessado o tráfico de escravos. Assim a partir da publicação desta lei, a aquisição da propriedade de terras passou a se dar somente mediante compra e venda, impedindo que os antigos escravos por não possuírem recursos adquirissem pela posse a propriedade das terras brasileiras.

A partir de então a propriedade rural entrou no comércio e tornou-se, mais ainda, instrumento de poder político e econômico. Entretanto, a questão fundiária até hoje não está resolvida. Na verdade, não se sabe, ainda, em sua totalidade, o que é terra devoluta e o que pertence ao patrimônio particular. Por isso, criou-se institutos ligados à regularização fundiária como os institutos da ação discriminatória, da legitimação de posse e regularização de posse.

A ocupação produtiva e adequada do território brasileiro ainda é uma questão acesa, mal resolvida, cujas consequiências de ordem social são sensíveis. Isto tem levado os sucessivos governos, em todas as esferas, à medidas, ainda que bem intencionadas, nem sempre consentâneas com o bem estar da população e com a necessidade de preservação do meio ambiente.

\section{FONTES BIBLIOGRÁFICAS}

ALBUQUERQUE FILHO, Clóvis Antunes Carneiro de. A importância dos módulos rurais na distribuição e aproveitamento da terra . Jus Navigandi, Teresina, ano 4, n. 46, out. 2000. Disponível em: .<http://jus2.uol.com.br/doutrina/texto.asp?id=1675>. Acesso em: 19 maio 2008.

ALMEIDA Roberto Moreira de. Sesmarias e terras devolutas. Revista de Informação Legislativa. Brasília, a. 40, n. 158 abr./jun. 2003, p. 309 -317. 
ALVARENGA, Octávio Mello. Contratos agrários. Brasília: Fundação Petrônio Portella, 1982. (Curso de Direito Agrário, 8).

ALVES, Fábio. Direito Agrário: Política Fundiária no Brasil. Belo Horizonte: Del. Rey, 1995.

BALLESTERO HERNANDEZ, Luis Martin. Derecho Agrário: estudios para una introducción. Zragoza: Manuales y estúdios,1990.

BARROS, Sérgio Resende de Autonomia do Direito Agrário Brasileiro, Revista Procuradoria Geral do Estado de São Paulo, São Paulo, n. 29, p. 259-278, jun. 1988.

BARRoso, Lucas Abreu . Atividade Agrária Como Eixo Central Do Conceito De Direito Agrário. Disponível em: < http://www.estig.ipbeja.pt/ ac_direito/Atividade.doc >. Acesso em 25 maio 2008.

. (Org.) O Direito Agrário na Constituição. Rio de Janeiro: Forense, 2005, p. 271-303.

BELLEN, Hans Michael Van. Desenvolvimento Sustentável: Uma Descrição das Principais Ferramentas de Avaliação. Ambiente \& Sociedade, v. VII, n. 1, p. 67-88, jan./jun. 2004.

BIDART, Adolfo Gelsi. Um Aspecto de Derecho Agrario y Ambiente. In: Direito Agrário no Mercosul, EDUCP, 1998.

BONONI, Alexandre Bottino. Políticas Agrícolas: Principais Instrumentos Governamentais para o fomento das atividades agrícolas. ( a intervenção do Estado na agricultura) SANTOS, Márcia W., QUEIROZ, Eduardo Lopes.(Coord.). Direito do Agronegócio. Belo Horizonte:Forum, 2005, p. 98-129.

BORGES, Marcos Afonso. Processo Judicial da Ação Discriminatória. 2. D. Goiânia:AB, 1998

BORGES, Paulo Torminn. Institutos Básicos do Direito Agrário. $11^{\mathrm{a}}$ ed. São Paulo,Saraiva, 1998.

BORGES, Roxana Cardoso Brasileiro. Função ambiental da Propriedade Rural In.

BRASIL, Estatuto da Terra, Lei n. 4.504, de 30 de novembro de 1964. Disponível em: <http://www.planalto.gov.br> . Acesso em: 15 jul. 2008, 12:20:19.

COMPARATO, Fábio Konder. Direitos e Deveres Fundamentais em Matéria de Propriedade. A questão Agrária e a Justiça. São Paulo: RT, 200?, p. 130-147. 
CUNHA JÚNIOR, Dirley da, Terras devolutas nas constituições republicanas Disponível em:. <http://www.jfse.jus.br//obras\%20mag/artigoterrasdevdirley.html>. Acesso em 25 maio 2008 .

CARROZZA, Antônio. Gli Isttituti del Diritto Agrário. v. 1. Milano: Dott.A.Giuffrè Editore, 1962. v. 2. Milano: Dott.A.Giuffrè Editore, 1970.

CRETELA JUNIOR, José. Tratado de domínio público. Rio de Janeiro: Forense, 1984.

DELGADO DE MIGUEL, Juan Francisco. Derecho Agrário de la Unión Europea. Oviedo: Thebook, 1994.

Estudios de derecho Agrário. Madrid: Montecorvo, 1993.

DRESCH, Renato Luís. A repercussão da Função Social da Propriedade nas Ações Possessórias. In: BARROSO, Lucas de Abreu et ali (Coord.) A lei agrária Nova, volume I, Curitiba: Juruá, 2006.

ESPÍNDOLA, Ruy Samuel. Conceito de princípios Constitucionais. 2. Ed. São Paulo: RT, 2002.

FALCÃO, Ismael Marinho. Direito Agrário Brasileiro, EDIPRO, 1995.

Direito e reforma agrária. Jus Navigandi, Teresina, ano 4, n. 39, fev. 2000.

Disponível em: <http://jus2.uol.com.br/doutrina/texto.asp?id=1671>. Acesso em: 09 maio 2008.

FERRAZ JUNIOR, Tércio Sampaio. A Ciência do Direito, 2. Ed. São Paulo:Atlas, 1980

GLOSSÁRIO DE DIREITO AGRÁRIO, do Curso de Especialização em Direito Agrário e Curso de Mestrado em Direito Agrário da UFG,Goiânia:Potência, 1998.

GODOY, Luciano de Souza. Direito Agrário Constitucional, O Regime da Propriedade. Atlas Jurídica, São Paulo, 1998.

GRAZIANO, Xico. O Paradoxo agrário. Campinas: Pontes, 1999.

JARQUE, Jan José Sanz Jarque. Derecho Agrário, Geral Autonómico y Comunitario, v. 1 Introducion: Mocion, natureza y fuentes Madri: Instituto Editorial Reus, 1985.

JONES, Alberto da Silva. Lei de Terras, Propriedade Territorial e Relação Latifundiária: um Fracasso de um Projeto Capitalista para a agricultura brasileira. Economia Rural, ano 7.

Out./dez. 1996, n. 4 DER-UFV- Viçosa- MG. p. 10-16. 
JUNQUEIRA, Messias. As Terras Devolutas na Reforma Agrária, in Ed. Revista dos Tribunais, São Paulo, 1964

O Instituto Brasileiro das Terras Devolutas. São Paulo: Edições LAEL, 1976

KAUCHAKJER, Samira Gestão e controle das políticas públicas: participação Social no Brasil contemporâneo. Humanas, v. 26/27, n.1/2, p. 231-249, Porto Alegre, 2004/2005.

LAKATOS, Eva Maria, MARCONI, Marina de Andrade. Fundamentos de Metodologia Científica, 6. Ed, São Paulo: Atlas, 2006.

LAMARCHE, H. (Coord.). A Agricultura Familiar. Campinas: Ed. UNICAMP, 1993.

LARANJEIRA, Raymundo Política Agrária: segurança alimentar, transgênicos e soberania nacional. In. BARROSO, Lucas de Abreu, et al (Org.) O Direito Agrário na Constituição. Rio de Janeiro: Forense, 2005, p. 187-222.

LARENZ, Karl. Metodologia da Ciência do Direito, 3 ed. Trad. de Jorge Lamego, Lisboa: Fundação Calouste Gulbekian, 1997.

LEITE José Luís Marasco C. A Apropriação das Terras Brasileiras Anotações Preliminares, Rev. Esc. Direito, Pelotas, 5(1): 7-22, Jan.-Dez./2004.

MAGALHÃES, Barcellos de Comentários à Constituição Federal de 1988, vol. I, Editora Lumen Juris, 1997.

MANIGLIA, Elisabete. Atendimento da Função Social pelo Imóvel Rural. BARROSO, Lucas de Abreu, et al (Org.) O Direito Agrário na Constituição. Rio de Janeiro: Forense, 2005, p. 25-44.

MARQUES, Benedito Ferreira A desapropriação da Propriedade produtiva para fins de Reforma Agrária Revista Goiana de Direito Agrário , ano.2, n. 2, Goiânia: Gráfica e editora Renascer, 1998, p. 63-69.

. Direito Agrário Brasileiro, Goiânia, AB, 2005.

MARQUES, Daiane da Cunha. Uma Análise Sócio- Jurídica da Parceria Rural em Ervália MG. 2007. 138f. Dissertação (Pós-Graduação em Extensão Rural)- Universidade Federal de Viçosa, Viçosa, Minas Gerais ,2007.

MATTOS NETO, José de. A posse agrária e suas implicações jurídicas no Brasil. Belém:CEJUP, 1988.

MIRANDA, Alci Gursen de. O instituto Jurídico da posse agrária. Belém:CEJUP, 1992. 
MIRANDA, Custódio da Piedade. Natureza Jurídica das Sesmarias. In: Revista do Direito Agrário. Brasília. 10 (9), p. 9-13, $1^{\circ}$ sem. 1983.

NEVES, Castanheira A. Metodologia Jurídica: Problemas fundamentais. Coimbra, Portugal: Coimbra Editora, 1993.

OLIVEIRA, Umberto Machado de. Princípios de Direito Agrário na Constituição Vigente, Curitiba: Juruá, 2008.

RIZZARDO, Arnaldo. O Uso da Terra no Direito Agrário. 3.ed., Rio de Janeiro:AIDE, 1985.

SANTOS, Fábio Alves dos. Direito Agrário. Política Fundiária no Brasil. Belo Horizonte, Del Rey, 1995.

SANZ JARQUE, Juan Jose. Derecho agrario: general, autonomico, comunitario. Madrid: REUS, 1985. v.1.

SILVA, Jônathas. O direito e a Questão Agrária na Constituição brasileira. Goiânia: Ed. UCG, 1996.

SILVA, José Afonso. Direito de propriedade In. . Curso de Direito Constitucional Positivo, Malheiros, 22. ed., 2003, p.269-282.

SILVA, Leandro Ribeiro. Propriedade Rural. Rio de Janeiro: lumen Juris, 2001.

SODEVILLA Y VILLAR, Antonio D. Derecho agrario (lecciones para un curso). V. III parte especial 2. Valladolid, 1999.

SOUSA, João Bosco. Direito Agrário. Lições Básicas. 3.ed. São Paulo, Saraiva, 1994.

STEFANINI, Luiz Lima. A Propriedade no Direito Agrário. São Paulo: Revista dos Tribunais, 1978

TEPEDINO, Gustavo. Contornos Constitucionais da Propriedade Privada. Temas de Direito Civil. 3. ed. Rio de Janeiro: Renovar, 2004.

VIAL, Propriedade da terra: uma análise sociojurídica. Porto Alegre: Livraria do Advogado Editora, 2003.

TELLO, Vanin. Derecho agrario: teoria general. Colombia: Universidad Externato de Colombia, 1985.

VIAL, Sandra Regina. Propriedade da terra: uma análise sociojurídica. Porto Alegre: Livraria do Advogado Editora, 2003.

VIVANCO, Antonio C. Teoria de derecho agrario. La Plata: Libreria Juridica, 1967. 4 v. 
ZELEDON ZELEDON, Ricardo. Teoria General e Institutos de Derecho Agrário, Buenos Aires, Astrea, 1990. 